hom
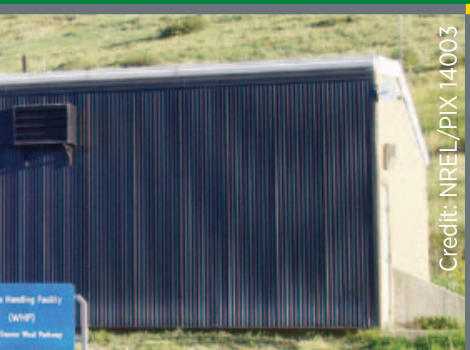

ind

The transpired solar collector on the National Renewable Energy

Laboratory's Waste Handling Facility in Golden, Colorado.

\title{
TRANSPIRED SOLAR COLLECTOR AT NREL'S WASTE HANDLING FACILITY USES SOLAR ENERGY TO HEAT VENTILATION AIR
}

The transpired solar collector (TSC) installed on the National Renewable Energy Laboratory's (NREL) Waste Handling Facility (WHF) in Golden, Colorado, is one of the earliest applications of this technology and the first use of the technology at a Federal facility. Since its installation in 1990, the system has provided solar pre-heated ventilation air to contribute to meeting the high heat ventilation air requirements of this facility. The TSC is an efficient alternative for pre-heating ventilation air and can improve indoor air quality in facilities with large ventilation air needs.

The NREL WHF was an ideal candidate for the TSC technology. The facility is a 1,300 square foot $\left(\mathrm{ft}^{2}\right)$ chemical waste storage building that requires a ventilation rate of 3,000 cubic feet per meter (CFM) to maintain safe indoor conditions. Because open flames are prohibited in the building due to the
The U.S. Department of Energy's (DOE) Federal Energy Management Program (FEMP) facilitates the Federal Government's implementation of sound, cost-effective energy management and investment practices to enhance the nation's energy security and environmental stewardship.

\section{Highlights}

System Size

Energy Production

Installation Date

Motivation

Annual Savings

\section{System Details}

Components

\section{Storage}

Loads

Parameter Measured

Expected Life

Supplier danger of combustion, ventilation air is heated with electricity instead of gas. The WHF has a large, south-facing wall area with only one penetration. Finally, the addition of the TSC was an acceptable architectural change to the building.

The $300 \mathrm{ft}^{2}$ transpired collector saves about 14,310 kilowatt hours ( $\mathrm{kWh}$ ) annually ( $25.7 \%$ of the energy required to heat the facility's ventilation air). In addition, the system annually avoids 14.9 tons of carbon dioxide $\left(\mathrm{CO}_{2}\right)$ and 52 pounds of nitrogen oxide $\left(\mathrm{NO}_{\mathrm{x}}\right)$ emissions. With a 2005 installation cost of $\$ 20 / \mathrm{ft}^{2}$ and a utility cost of $\$ 0.054 / \mathrm{kWh}$, NREL saves $\$ 726$ a year in electric bills. This investment results in a nine-year simple payback. Over the 25-year study period, the life-cycle savings are expected to equal $356,527 \mathrm{kWh}$. Over its life cycle, the system will provide energy to the site at an equivalent energy rate of $\$ 0.02 / \mathrm{kWh}$ of heat.

\section{How the Technology Works}

The transpired collector is a dark-colored, perforated metal wall installed on a south-facing side of a building, creating an approximately 6 in. 
$(15 \mathrm{~cm})$ gap between it and the building's structural wall. The size of the wall varies depending on heating and airflow requirements and climate. Recommended size is $0.25 \mathrm{ft}^{2}$ of TSC per CFM of ventilation air $\left(4 \mathrm{CFM} / \mathrm{ft}^{2}\right)$. In many applications, the TSC will cover the maximum south-facing area available. However, oversizing is not cost effective. The dark-colored wall acts as a large solar collector that converts solar radiation to heat. Fans associated with the building's ventilation system draw outside air through the transpired collector's perforations, and the thermal energy collected by the wall is transferred to the air passing through the holes. The fans then distribute the heated air into the building. A bypass damper activated on warm days and during the summer ensures that solar-heated ventilation air is provided only when heating is needed.

The technology is truly a building-integrated solar system because the system depends on the space between the perforated absorber area and the exterior wall of the building to collect and move heated air. A large, south-facing wall area is required for a TSC installation $\left( \pm 45^{\circ}\right.$ of south is often acceptable). This wall must have minimal penetrations and must not be designed to be an explosion blowout wall. The TSC absorber comes in four standard colors (all dark) and many other colors with associated minimum order and lead times, providing architectural flexibility. However, designers should be aware that the overall efficiency of the system decreases for lighter colors. Collectors can be added on to an existing building or designed as part of a new one. These systems can pay for themselves even faster in new construction because they offset part of the costs for the building's façade.

By preheating ventilation air with solar energy, the technology removes a substantial load from a building's conventional heating system, saving energy and money. At night the system can further assist in heating by



recapturing heat lost through the building wall behind the collector. The transpired collector system can also help meet demands for improved indoor air quality, because better ventilation is an integral part of the system.

\section{Performance}

NREL's unglazed TSC has been in continuous operation for 15 years. Initial detailed measurements indicated that the average system efficiency was $63 \%$. The collector was installed in front of an existing concrete wall.

In general, each square foot of transpired collector will raise the temperature of $4 \mathrm{CFM}$ of air by as much as $40^{\circ} \mathrm{F}$, delivering approximately 240,000 British thermal units (Btu) annually per square foot of installed collector; but as shown in the map, savings are heavily dependent on sunlight and the need for heat. Typical annual efficiency for these systems is between $60 \%$ and $65 \%$.

NREL has found many advantages with TSC. These include:

- The system requires minimal maintenance, with no liquids and no moving parts other than the ventilation system fans. The collector system should still be inspected periodically for physical damage and for proper operation of controls.

- The collector system was easily added to the building as a retrofit.

- The system is an effective way to capture renewable energy benefits for this ventilation air preheat application.

\section{Project Partners and Funding Sources}

The WHF system was designed and installed by Conserval Systems, Inc. and NREL. NREL researchers instrumented the system and monitored its performance.

\begin{tabular}{|l|l|}
\hline \multicolumn{2}{|c|}{ Cost Breakdown (2005 US\$) } \\
\hline $\begin{array}{l}\text { System cost (includes collector equipment } \\
\text { and labor for design and field supervision) }\end{array}$ & $\$ 6,000$ \\
\hline Equivalent energy rate & $5.58 /$ million Btu $(\$ 0.02 / \mathrm{kWh})$ \\
\hline Annual O\&M cost & $\begin{array}{l}1 \% \text { of the system costs per } \\
\text { year }(\$ 45 / \text { year) }\end{array}$ \\
\hline Net present value & $\$ 5,163$ \\
\hline Savings to investment ratio & 1.86 \\
\hline Adjusted internal rate of return & $5.59 \%$ \\
\hline
\end{tabular}

${ }^{1}$ The equivalent energy rate is the present value of the initial cost and recurring O\&M costs divided by the present value of life-cycle energy savings, calculated using building life-cycle cost version 5.3-05 for a 25-year study period.

\section{Contacts:}

Andy Walker

National Renewable Energy Laboratory

303-384-7531

andy.walker@nrel.gov
Anne Sprunt Crawley

Technology Manager

U.S. Department of Energy

FEMP

202-586-1505

anne.crawley@ee.doe.gov
U.S. DEPARTMENT OF
For more information contact:

EERE Information Center

1-877-EERE-INF (1-877-337-3463) www.eere.energy.gov/informationcenter

Printed with a renewable-source ink on paper containing at least $50 \%$ wastepaper. including $10 \%$ post consumer waste.
Prepared by the National Renewable Energy Laboratory (NREL), a national laboratory

of the U.S. Department of Energy, Office of

Energy Efficiency and Renewable Energy;

NREL is operated by the Alliance for

Sustainable Energy, LLC.

DOE/GO-102010-3096 • September 2010 